\title{
Evaluation of the Epidemiological Factors Responsible for the Appearance of Phytophthora Palmivora and Phytophthora Megakarya, Causal Agent of Black Pods Disease in the Department of Méagui, Southwestern Côte D'ivoire
}

\author{
F. Z. Oro ${ }^{1}$, H-D. Lallié ${ }^{2}$, G K. Brou ${ }^{1}$, A D. Koffi ${ }^{1}$, L. Blondin ${ }^{3}$, \\ C. Neema ${ }^{3}$, C. Cilas $^{4}$, H A. Diallo ${ }^{5}$
}

\begin{abstract}
${ }^{1}$ Department of Plant Biology, Faculty of Biological Sciences. Peleforo GON COULIBALY University. BP 1328 Korhogo (Côte d'Ivoire)

${ }^{2}$ Département of Genetics-Biochemistry, Faculty of Biological Sciences. Peleforo GON COULIBALY University. BP 1328 Korhogo (Côte d'Ivoire)

${ }^{3}$ CIRAD, BGPI, Montpellier SupAgro, INRA, Univ. Montpellier, Cirad, Campus de Baillarguet, 34398,

Montpellier, France

${ }^{4}$ CIRAD, Bioagresseurs, Univ. Montpellier, Cirad, Campus de Baillarguet, 34398, Montpellier, France

${ }^{5}$ Phytopathology Research Unit, Department of Plant Protection and the Environment, Nangui Abrogoua University. 02 BP 801 Abidjan 02
\end{abstract}

\begin{abstract}
The cocoa black pod disease is caused by a fungus Phytophthora sp, which comprises two main species (Phytophthora palmivora and Phytophthora megakarya) commonly found in Ivorian cocoa plots and which cause significant damage. Despite numerous studies, this disease continues to spread and even more so Phytophthora megakarya, which did not exist in Côte d'Ivoire, is beginning to spread significantly. This study focused on the evaluation of the epidemiological factors responsible for the progression of Phytophthora megakarya and Phytophthora palmivora in the Department of Méagui, southwestern Cote d'Ivoire. To this end, a prospective survey was conducted in three cocoa plots in Méagui, which collected epidemiological data on "Foliar coverage rate", "Maintenance level" and the prevalence of black pod. Molecular data on black pod disease isolates were extracted from immature pods with black pods symptoms. A descriptive analysis was first applied to the data to understand their dispersion, followed by a comparative analysis (student's t-test) to evaluate the relationship between epidemiological parameters and disease prevalence. Finally, a molecular analysis in the laboratory made it possible to characterize the different species of Phytophthora sp. The results of the molecular analysis showed the presence of Phytophthora megakarya at $79 \%$ against $21 \%$ for Phytophthora palmivora. The results of the student t-test showed that this prevalence of black pod is related to the lack of plot maintenance $(\mathrm{P}=0.036<0.05)$ and high leaf coverage of cocoa trees $(\mathrm{P}=0.003<0.05)$. However, distribution maps of the different species show that Phytophthora megakarya is the most dominant species on the Méagui site.
\end{abstract}

Keywords: Cocoa, Maintenance Level, Foliar Coverage, Phytophthora sp.

\section{Introduction}

Cocoa tree is a perennial plant originating from the humid tropical forests of America. It belongs to the Malvaceae family (Guyot, 1992), and to the genre Theobroma. It is cultivated for its beans used to make chocolate. Most of the production (70\%) comes from Côte d'Ivoire and Ghana (Lass 2004). Cocoa farming in Côte d'Ivoire accounts for $40 \%$ of exports and $15 \%$ of gross domestic product (ICCO 2015). This crop employs more than 1,000,000 farmers and supports more than 3,000,000 people in the secondary and tertiary sectors of the Ivorian economy. Nevertheless, cocoa farming is subject to high parasitic pressure due to diseases and pests. One of the most important diseases affecting cocoa farms in Côte d'Ivoire is black pod (Kébé et al. 1996; Kébé 1999). Black pod is a fungal disease caused by the genre Phytophthora sp. Phytophthoras are Oomycetes of the family 
Peronosporaceae. Symptoms observed on cocoa trees are generally localized on the fruit (Fig1), on the trunk and sometimes on the leaves. Pods are sensitive at each stage of their development and can be infected at any location on all surfaces. The first symptoms begin with blacking, which later becomes a stain on the pod. This spot spreads rapidly either from top to bottom (Fig1a) or from bottom to top of the infected pod (Fig1b). Water is the main carrier of inoculum. It is under the action of water that sporocysts explode to produce zoospores that are carried by rainwater (Akrofi 2015). Other factors that spread the disease include insects, various animals including rodents and especially humans. Black Pod disease spreads faster when the humidity is high. Indeed, it is favoured by dense shade when the planting density is high or when there is a strong presence of shade trees in the plot with a very large grass cover or proximity to a watercourse (CoffeeCocoa Council 2015). Two species of Phytophthora $s p$ are found in cocoa farms in Côte d'Ivoire. These are Phytophthora palmivora, which is the most widespread and least aggressive species causing yield losses of around 40\%, and Phytophthora megakarya, which is very aggressive and less known with damage estimated at nearly 60 to $100 \%$ (Flood 2006). In Côte d'Ivoire, black pod has long been attributed to Phytophthora palmivora, but in recent decades, Phytophthora megakarya, which did not exist in Côte d'Ivoire, has appeared in cocoa plantations (Kébé 1999). The presence of Phytophtora megakarya has been reported since 1998 in eastern Côte d'Ivoire, along the entire border with Ghana where significant crop losses have been recorded (CNRA 2007). Since 2006, the first isolates of Phytophtora megakarya have been identified in Abengourou and Méagui. This study was extended in 2007 to the Department of Soubré, which is the current cocoa loop. In this Department, two isolates of this Phytophthora species have been identified (CNRA 2007). The identification of Phytophthora megakarya was confirmed in 2013 in southeastern Côte d'Ivoire towards the border with Ghana where nearly 60 to $80 \%$ of crop losses were recorded (Pohe et al. 2013). At the same time, another study was conducted in southwestern Côte d'Ivoire to characterize Phytophthora spp. isolates, but the latter study revealed only the presence of the single palmivora species (Coulibaly et al. 2013). These results clearly show that the exact distribution of this new species is not well known throughout the national territory. The increasing yield losses observed by producers each year in southwestern Côte d'Ivoire due to black pod could be linked to Phytophthora megakarya. To remove the ambiguity, this study is initiated to attest not only to the presence of Phytophthora megakarya from molecular analyses, but also to evaluate the epidemiological factors responsible for the development of both Phytophthora palmivora and Phytophthora megakarya in the Department of Méagui. Specifically, it will first identify the different species of Phytophthora $s p$, then evaluate the epidemiological factors responsible for the appearance of each species of Phytophthora ssp and finally establish the distribution map of each species of Phytophthora sp.

\section{Materials and methods \\ 2.1 Study area}

This study was conducted in Méagui ( $5^{\circ} 24^{\prime} 43^{\prime \prime}$ North, $6^{\circ} 33^{\prime} 37^{\prime \prime}$ West), one of the Departmental capitals of the Nawa region, South West Côte d'Ivoire (Fig2). This region was chosen because it constitutes the current cocoa loop, with, for the 2013-2014 campaign, about 320,000 tons, or nearly $20 \%$ of national production (Coffee-Cocoa Council 2014). The Department of Méagui is a forest area whose vegetation is essentially dominated by dense forest with deep, permeable and well-drained soil capable of supporting all types of crops, especially cocoa (Ngo et al. 2012). The climate of the Nawa region is of a sub-equatorial type locally called "Attieen climate" (Yao 2009). This climate is characterized by heavy rainfall, which oscillates between $1300 \mathrm{~mm}$ and $1600 \mathrm{~mm}$ depending on the year and location. The atmospheric humidity is high (90\%) with a low annual variation in temperature amplitude (between 26 and $28^{\circ} \mathrm{C}$ ). The climate is characterized by a dry season (December-March) and two rainy seasons (April-June and September-November). These climatic characteristics, marked by high precipitation and a long period of relative humidity, make it a zone with high parasitic pressure.

\subsection{Material}

The plant material used in this study includes 66 cocoa trees (Theobroma cocoa) from which 66 pods affected by black pod were collected. The survey took place in three peasant farms. To remove these pods affected by black pod, a pruning shear was used to cut the pod. Once the pods have been removed, they are packaged in newspaper to prevent the rot from spreading, then with adhesive tape, fasteners are made around the pod and labelling has been done with an indelible marker. The Global Positioning System (GPS) coordinates of the cocoa trees sampled were recorded with a Garmin 64s GPS. Survey sheets were completed to compile physical data. Once in the laboratory, the samples of pods affected by black pod were crosscut with a knife following the evolution of the rot and then a scalpel was used to remove small pieces of pod (explants) from the cortex after the crosscut. These decay explants are placed in 
eppendorf tubes containing agar medium (H2OAgar).

\subsection{Methodology \\ 2.3.1. Prospective survey}

This study was carried out through a prospective survey. These surveys were carried out in three peasant farms in Méagui. To this end, a survey sheet was prepared containing several parameters that were evaluated in the field. These were date, study area, study site, sample code, tree number, geographical coordinates (longitude in decimal degrees, and latitude in decimal degrees), total number of pods, number of rotten pods, level of maintenance, foliar coverage rate and description of symptoms observed on the pods collected.

\subsubsection{Observation}

Observations were randomly made on 66 cocoa trees with pods affected by black pod in three peasant plots, i.e. 22 cocoa trees observed per plot. For each tree, observations were made on the total number of pods, as well as the number of rotten or healthy pods from the trunk to the canopy of the test tree. The state of maintenance was also observed at the scale of each plot. The coverage rate was evaluated through the foliar crown of the cocoa tree.

\subsubsection{Data collection}

Data on epidemiological factors were collected, including the total number of pods, the number of rotten pods, the prevalence of black pod, the level of maintenance of cocoa plots and the cocoa tree coverage rate. Indeed, the total number of pods was obtained by counting all pods on each test cocoa tree. This variable includes both the number of healthy pods and the number of pods affected by black pod. Then, the number of rotten pods was deducted from the total number of pods observed on each test cocoa tree. Each test cocoa tree was the subject of a geographical coordinate survey. These geographical coordinates made it possible to establish the distribution map of the different species of Phytophthora sp.

The prevalence of black pod was determined from the ratio of the total number of pods to the number of pods affected by black pod using the following formula:

$P(P b \%)=\frac{\text { Number of rotten pods (ICAB) }}{\text { Total number of pods produced (TCAB) }} X 100$

$\mathrm{P}(\mathrm{Pb} \%)$ : prevalence of black pod in percentage.

The prevalence of each Phytophthora $s p$ species was also determined by taking into account the number of infected pods per Phytophthora $s p$ species and the total number of pods produced.

The level of maintenance of the plots has been evaluated. This is a qualitative data with two modalities (maintained or not maintained). This variable relates to regular weeding, draining and pruning of the test plot. The coverage rate of cocoa trees is evaluated at the tree level. It is a qualitative variable with three modalities (low, medium and high). The high coverage rate is characterized by a strong canopy of the tree with a strong shade while the low coverage rate is characterized by a weak foliage of the tree often allowing light to penetrate the undergrowth. At the intersection of these two modalities is the average coverage rate. Molecular data were also collected. These molecular data relate to the black pod isolates collected from the rotten pod samples. Indeed, a sample of pods showing the beginning of rot was collected on each cocoa tree test stock. Once collected, the pod samples are packaged in newsprint to limit the progression of black pod disease. These samples are then numbered and labelled and transported to the laboratory. Once in the laboratory, each pod sample was crosscut to extract an explant from the cortex of the rotten pods following the evolutionary front of the rot. The explants collected are temporarily packaged in eppendorf tubes, containing an agar medium (H2OAgar) favourable to the development of Phytophthora $s p$. These different tubes were then labelled according to the identification code since the field sampling. A total of 66 black pods isolate samples were sent to the BGPI laboratory of CIRAD Montpellier for molecular analyses.

\subsection{Data analysis}

\subsubsection{Molecular characterization of Phytophthora $s p$ isolates}

In the laboratory in Montpellier, the sampled explants were cultured in petri dishes on the "V8" medium, which consists of a $1 / 10^{\text {th }}$ vegetable juice cocktail, agar at $15 \mathrm{~g} / \mathrm{L}$ and $\mathrm{CaCO} 3$ at $3 \mathrm{~g} / \mathrm{L}$ for 4 days in the dark, at $25^{\circ} \mathrm{C}$. After 4 days, agar implants containing Phytophthora mycelium were removed from the fungal growth forehead with a scalpel and then transplanted back to the V8 medium under the same conditions described above for 7 days. The resulting mycelium is used for DNA (Deoxyribonucleic Acid) extraction. In the case where the strains are contaminated by other fungi, several transplants on $\mathrm{H} 2 \mathrm{O}$-Agar culture medium at $15 \mathrm{~g} / \mathrm{L}$ are necessary to purify the strain. After purification, the strain is cultured again on the "V8" medium at $25^{\circ} \mathrm{C}$ for 4 days and then for 7 days in the dark to obtain a mycelium typical of Phytophthora sp. The mycelium obtained after purification is used for DNA 
extraction. The identification of the different Phytophthora species was carried out using PCR (Polymerase Chain Reaction) with ITS (Internal Transcribed Spacer) primers specific to each species (P. megakarya and P. palmivora).

\subsubsection{Distribution Mapping of Phytophthora sp. species}

The results of the molecular analysis were coupled with the geographical coordinates of the cocoa trees from which the samples of rotten pods were taken. The coupling of these coordinates with molecular data made it possible to produce distribution maps of the Phytophthora sp species identified in the Department of Méagui

\subsubsection{Evaluation of epidemiological factors in the progression of black pod disease}

The descriptive analysis of the epidemiological data allowed to determine on the one hand the minimum, maximum, average and standard deviation of the quantitative variable represented by the prevalence of black pod over the entire study site and the determination of the numbers and frequency of the qualitative variables relating to the foliar cover rate of cocoa trees and the level of maintenance of the plots surveyed on the other hand. The number and percentage of pods infected by each Phytophthora $s p$ species was also determined. The data from the molecular analysis determined the frequency and distribution maps of each Phytophthora sp species identified at the Méagui site using IBM SPSS statistic.20 software. After checking normality using the Shapiro-Wilk test and variance homogeneity using the Levene test, the student t-test was applied. The student t-test first compared the averages of the "Not maintained" and "Maintained" modalities of the variable maintenance level (NE) of the plot, then the modalities "Medium" and "Strong" of the variable foliar coverage rate (TCF) of cocoa trees compared to the prevalence of black pod in cocoa pods. The Chisquare test was used to check the level of dependence between the foliar cover rate and the frequency of Phytophthora $s p$ species identified in Méagui. The Chi-square test was also applied to verify the dependence between the level of maintenance of the plot and the frequency of Phytophthora sp species identified at the Méagui site. Cramer's Phi and V test was applied to check the magnitude of the link between foliar cover rate and maintenance level in relation to the frequency of Phytophthora $s p$ species identified in Méagui. Boxplots were conducted to visualize this link between prevalence and these considered variables. These statistical tests were all performed at the 5\% threshold using the SPSS Statistics 20 software.

\section{RESULTS}

\subsection{Molecular characterization of species}

The results of the molecular analysis showed that out of 66 black pods samples analyzed, 52 were positive for P. megakarya, i.e. $78.8 \%$ and 14 for P. palmivora, i.e. $21.2 \%$. (Table 1). This result implies an epidemiological prevalence of $10.27 \%$ for $P$. palmivora and an epidemiological prevalence of $28.33 \%$ for P. megakarya at the Méagui site. The overall prevalence of the two species is $38.60 \%$ over the entire study site (Table 2).

\subsection{Distribution maps of the different species of Phytophthora sp}

The distribution map of the different species of phytophthora sp (Fig3) shows that P. megakarya is regularly distributed over all the sites of Méagui than $P$. Palmivora, which has a rather localized distribution. This is justified by a high distribution rate of $P$. megakarya around $78 \%$ compared to a low distribution rate of $P$. palmivora equivalent to $22 \%$.

\subsection{Influences of epidemiological factors on the prevalence of black pod}

The result of the descriptive prevalence analysis showed that black pod averaged $43.09 \%$ with a standard deviation of $\pm 19.94 \%$ at the Méagui site. This shows that prevalence data are less clustered around the average. The minimum prevalence is $11 \%$ and the maximum prevalence is $100 \%$. The description of the leaf coverage rate showed that most of the cocoa trees present at the Méagui site have a high leaf coverage with a frequency of $87.9 \%$ compared to $12.1 \%$ for moderately covered cocoa trees. The frequency of cocoa trees with low coverage is $0 \%$ at the study site. The result of the student t-test showed a highly significant difference $(\mathrm{P}=$ $0.003<0.05)$ between the prevalence of cocoa black pods and the leaf cover rate of cocoa trees (Table 3 ). The boxplots show this link visually (Fig4). The descriptive analysis of the data on the level of maintenance of the plots also showed that $67 \%$ of the sampled plots are not maintained, while only $33 \%$ of the plots benefit from regular maintenance (Table 4). The means of the modalities of the maintenance level variable (Not maintained: $46.70 \pm 20.55$ and Maintained: $35.87 \pm 16.83)$ compared to the prevalence of cocoa trees (Table 5). The result of the student t-test showed a significant difference $(\mathrm{P}=$ $0.036<0.05$ ) between the prevalence of cocoa black pods and the level of maintenance of cocoa fields (Table 5). The boxplots show this link visually (Fig5). The results of the Chi-square test showed no significant relationship (Chi-square $=0.078, \mathrm{ddl}=1$, $\mathrm{P}=0.780>0.05)$ between the frequency of appearance of the two phytophthora species and the different modalities of the level of maintenance of cocoa plots. 
Cramer's Phi and V test was not significant either (Phi and $\mathrm{V}$ to burn $=0.034<1, \mathrm{P}=0.78>0.05$ ).

\section{Discussion}

The results of the molecular analysis showed a predominance of Phytophthora megakarya (79\%) over Phytophthora palmivora (21\%). Indeed, $P$. megakarya is a very aggressive specie that was not widespread enough in Ivorian cocoa plots. This specie was recently discovered in 1998 in eastern Côte d'Ivoire along the border with Ghana. The increase in $P$. megakarya has clearly reached almost all cocoa production areas in Côte d'Ivoire. In fact, the damage caused by black pod has long been attributed to $P$. palmivora, which was more widespread in Côte d'Ivoire and less aggressive. The significant progression of this disease in Méagui could be due to the high proportion of $P$. megakarya. Some studies carried out by CNRA had shown the presence of $P$. megakarya in the Department of Méagui since 2006 (CNRA 2007). This result is corroborated with those obtained in this study that shows a strong expansion of $P$. megakarya. The combined effect of the two Phytophthora species greatly increases the prevalence of the epidemic of black pod disease in the Department of Méagui by $43.09 \%$. These results contradict those obtained by the study by Coulibaly et al (2013) which showed that $P$. palmivora was the most dominant specie and responsible for the cocoa black pods in southwestern Côte d'Ivoire. Today, this strong spread of $P$. megakarya in Ivorian cocoa plots, in addition to Swollen Shoot disease, is a real danger to Ivorian cocoa production. The result of the student t-test between prevalence and foliar coverage rate was highly significant $(\mathrm{P}=0.003<0.05)$. This significant link shows that the development of black pod in cocoa pods is strongly influenced by the high vegetative cover of cocoa trees. Indeed, the strong foliar coverage of cocoa trees creates shade under cocoa tree, which favours the maintenance of relative humidity. This humid microclimate is a determining factor in the development of fungal diseases, particularly in cocoa black pods disease. In addition, Tarjot (1971), in a study of the impact of various environmental factors on the development of black pod (due to Phytophthora palmivora) in Côte d'Ivoire, showed that high relative humidity increases the sensitivity of the fruit, as well as having a favourable effect on the development of the fungus. In addition, Medeiros (1976) links the evolution of black pods to climatic conditions, particularly relative humidity and rainfall. The low foliar coverage of cocoa trees favours the penetration of light into the undergrowth, thus reducing relative humidity. However, light has been identified as a growth inhibiting factor in different Phytophthora species
(Blaha 1983). Efombagn (1999) showed that the in vitro growth of phytophthora $s p$ isolates is influenced by light. He also noted that this growth is slow in continuous light, fast in darkness and average in alternating light (12 hours of light/12 hours of darkness). The results of this study are consistent with those obtained by the Coffee-Cocoa Council (2015), which showed that the development of black pod disease is influenced by the relative humidity associated with high cocoa tree shade. The student Test-t result showed a significant link $(\mathrm{P}=0.036<0.05)$ between the prevalence of black pod and the level of maintenance of the plot. This result indicates that the development of black pod can be attributed to the failure to maintain the plots. Indeed, weeding, draining and pruning of the plot are crucial operations in maintaining the cleanliness of the plot. These operations allow the destruction of the nests of certain pests such as insects that are capable of carrying the germs of the fungal pathogen. In addition, the Coffee-Cocoa Council has shown that weeds create a microclimate favourable to the proliferation of cocoa pests. Among these insects, many of them (ants, myriads, spiders...) are able to carry the germ from a rotten pod to a healthy pod. Other insects such as termites and ants, on the other hand, can carry the germ of the disease from the soil to the cocoa tree. While the description of the data relating to the level of maintenance of the plot showed that $67 \%$ of the cocoa plots sampled in Méagui are not maintained compared to $33 \%$ maintained. The result is confirmed by the studies carried out by Pohe et al (2013), indicating that the failure to maintain plots is linked to the demotivation of farmers who abandon cocoa farming in favour of other crops. This situation could be one of the determining factors in the increase in Phytophthora $s p$ and particularly $P$. megakarya, which was not very widespread in Ivorian cocoa plots. The Chi-square test and the Phi and V of burning test showed that the foliar coverage rate of cocoa trees was not at the origin of the appearance of one Phytophthora species compared to another. This implies that both the high leaf cover rate is a factor that can favour the appearance of $P$. megakarya, as well as the appearance of $P$. palmivora. The same applies to the level of maintenance factor of the plots of land.

\section{Conclusion, recommendations and perspectives}

At the end of this study, it should be noted that the level of maintenance and the foliar coverage rate are two epidemiological variables favourable to the development of cocoa black pods in Méagui. The high coverage rate of cocoa trees and the lack of maintenance of the plots had a greater influence on the development of cocoa black pods. Indeed, these two factors create a microclimate favourable to the 
Evaluation of the Epidemiological Factors Responsible for the Appearance of Phytophthora Palmivora and Phytophthora Megakarya, Causal Agent of Black Pods Disease in the Department of Méagui, Southwestern Côte D'ivoire

development of Phytophthora sp, which is responsible for black pods disease. Moreover, between the two species identified in Méagui, Phytophthora megakarya grows at a higher proportion (79\%) than Phytophtora palmivora (21\%) thus increasing the prevalence of the epidemic in the Department of Méagui. In view of these results, these recommendations can be observed for the control of black pod. This involves creating an aeration corridor around the farms by destroying the bush over a width of 5 to $10 \mathrm{~m}$ around it, maintaining the shade trees at a sufficient distance from each other to allow aeration of the farm, pruning the cocoa trees and carrying out the necessary weeding and finally carrying out the sanitary harvesting to stop the rapid spread of black pod disease in the farms. This requires regular removal of all affected pods as soon as the first typical stain appears. In the future, it would be interesting to extend the study to other sites in order to have a general idea of the prevalence of the megakarya species in south-west Cote d'Ivoire; to carry out a very detailed mapping study in order to establish a risk map in order to better develop control methods for better disease control and for a clearer monitoring of the progression of this very aggressive species, $P$. megakarya. It would be necessary to identify antagonistic fungi to Phytophthora $s p$ in order to carry out biological control.

Fig.1 Different typical symptoms of black pod disease on pods caused by Phytophthora palmivora and phytophthora megakarya. (a): Contamination of the pod from above, (b): Contamination of the pods from below, (c): Lateral contamination of the pods and (d): Shrunken beans, as a result of the phytophthora sp attack (Picture taken by Koffi Alain in 2018)

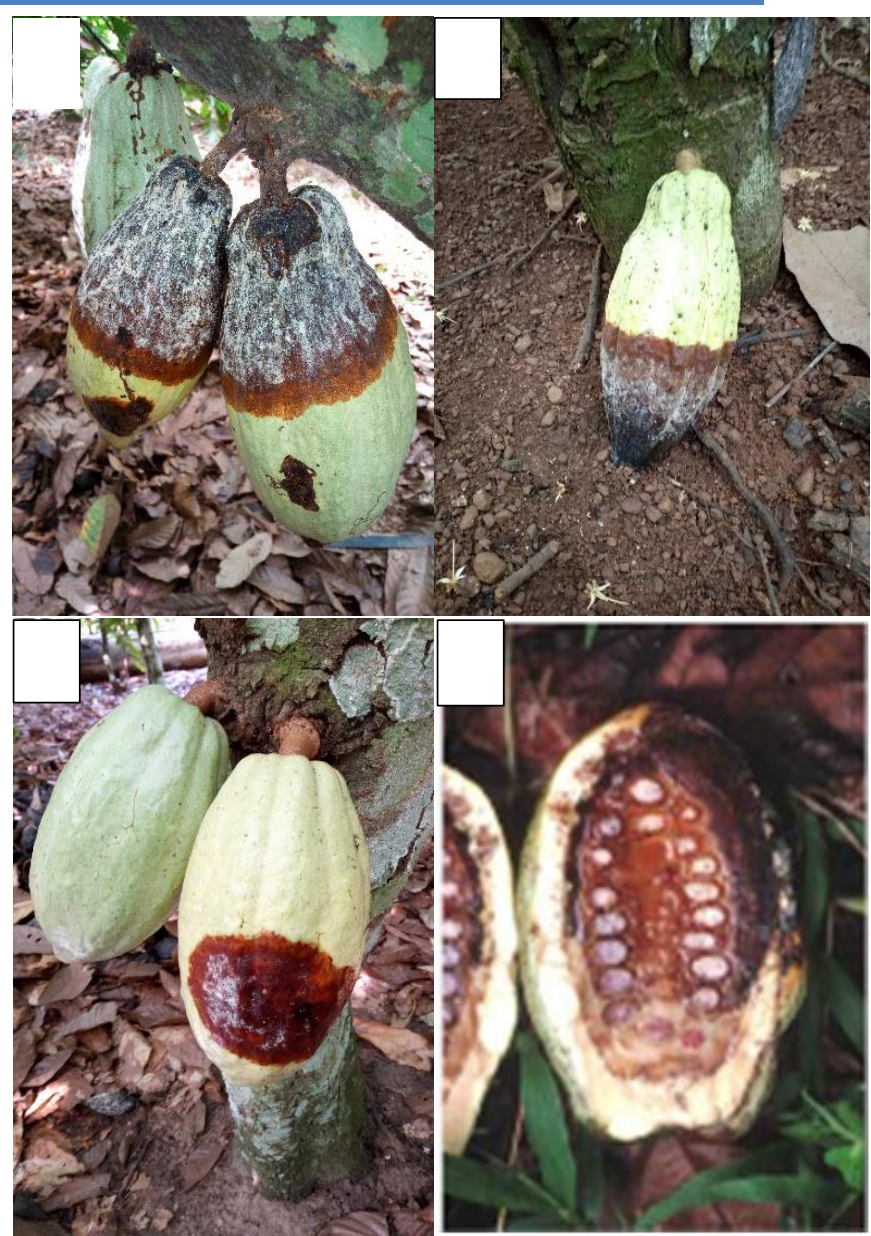

Fig.2 Map of the Nawa region showing the study site

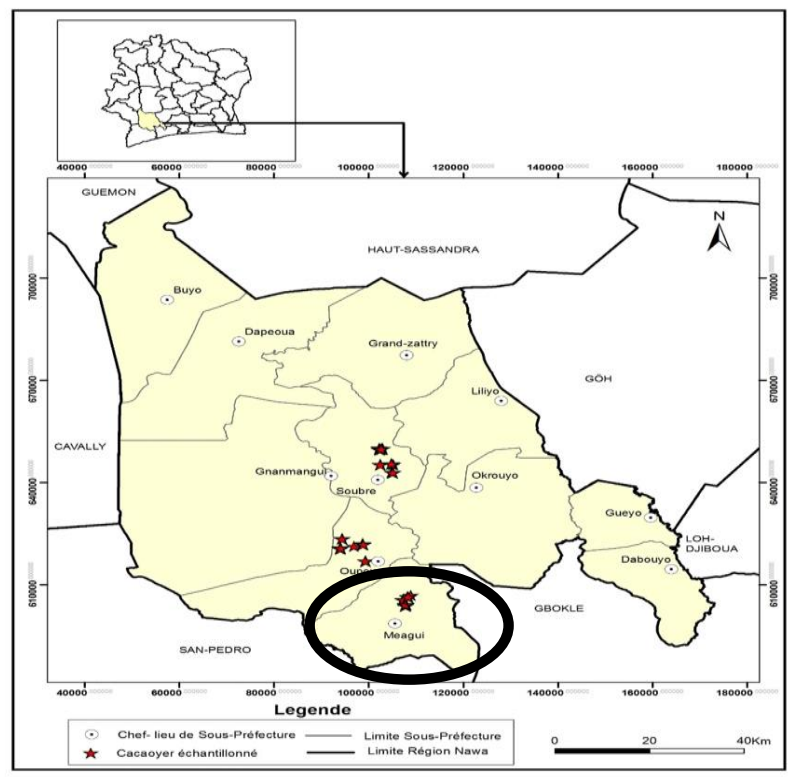


Evaluation of the Epidemiological Factors Responsible for the Appearance of Phytophthora Palmivora and Phytophthora Megakarya, Causal Agent of Black Pods Disease in the Department of Méagui, Southwestern Côte D'ivoire

Table 1: Descriptive statistics of the proportion of each species of Phytophthora $s p$

\begin{tabular}{cll}
\hline $\begin{array}{l}\text { Species } \\
\text { phytophthora sp }\end{array}$ & $\begin{array}{l}\text { Numb } \\
\text { er }\end{array}$ & $\begin{array}{l}\text { Percentag } \\
\mathrm{e}\end{array}$ \\
\hline $\begin{array}{l}\text { P. } \\
\text { palmivora }\end{array}$ & 14 & 21.2 \\
$\begin{array}{l}\text { P.megakar } \\
\text { ya }\end{array}$ & 52 & 78.8 \\
Total & 66 & 100 \\
\hline
\end{tabular}

Table 2: Number of pods infected by each Phytophthora sp species in Méagui

\begin{tabular}{lll}
\hline & $\begin{array}{l}\text { Number } \\
\text { of } \\
\text { infected } \\
\text { pods }\end{array}$ & $\begin{array}{l}\text { Prevalence of } \\
\text { Phytophthora } \\
\text { sp (\%) }\end{array}$ \\
\hline $\begin{array}{l}\text { P. palmivora } \\
\text { P.megakarya }\end{array}$ & 141 & $10.27 \%$ \\
Total infected pods & 530 & $28.33 \%$ \\
$\begin{array}{l}\text { Total non-infected } \\
\text { pods }\end{array}$ & 843 & $38.60 \%$ \\
Total sampled pods & 1373 & $61.40 \%$ \\
\hline
\end{tabular}

Fig.3 Distribution map of the two Phytophthora $s p$ species identified in Méagui

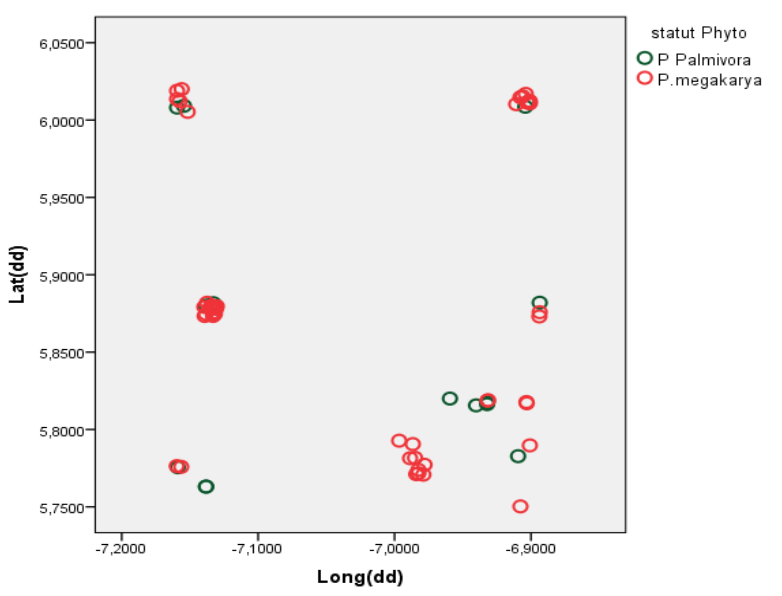

Table 3: Comparison table of foliar coverage rate according to the prevalence of black pod

\begin{tabular}{lll}
\hline & \multicolumn{2}{l}{ Prevalence(\%) } \\
\cline { 2 - 3 } & \multicolumn{2}{l}{ Foliar coverage rate } \\
\cline { 2 - 3 } & Average & Strong \\
\hline $\mathrm{N}$ & 8.00 & 58.00 \\
Average & 24.00 & 45.72 \\
Standard deviation & 10.11 & 19.55 \\
Average standard error & 3.57 & 2.56 \\
\hline & $\mathbf{P}=$ & \\
& $\mathbf{0 . 0 0 3}<\mathbf{0 . 0 5}$ & \\
\hline
\end{tabular}

Table 4: Descriptive statistics on the level of maintenance of the plot

\begin{tabular}{lll}
\hline $\begin{array}{l}\text { Level of maintenance of } \\
\text { the plots }\end{array}$ & Number & $\begin{array}{l}\text { Percentage } \\
(\%)\end{array}$ \\
\hline Not maintained & 44 & 66.7 \\
Maintained & 22 & 33.3 \\
Total & 66 & 100 \\
\hline
\end{tabular}

Fig.4 Boxplots of coverage rate according to the prevalence of black pod

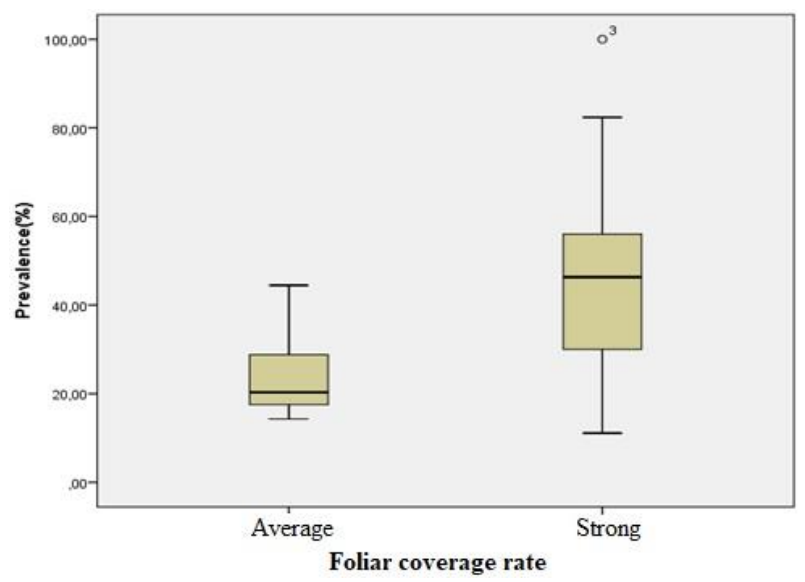


Evaluation of the Epidemiological Factors Responsible for the Appearance of Phytophthora Palmivora and Phytophthora Megakarya, Causal Agent of Black Pods Disease in the Department of Méagui, Southwestern Côte D'ivoire

Table 5: Comparison table of the average of the different groups of the maintenance level of the plot with the prevalence of black pod

\begin{tabular}{lll}
\hline & \multicolumn{2}{l}{ Prevalence(\%) } \\
\cline { 2 - 3 } & \multicolumn{2}{l}{ Level of maintenance } \\
\cline { 2 - 3 } & $\begin{array}{l}\text { Not } \\
\text { maintained }\end{array}$ & Maintained \\
\hline $\mathrm{N}$ & 44.00 & 22.00 \\
Average & 46.70 & 35.86 \\
Standard deviation & 20.55 & 16.83 \\
$\begin{array}{l}\text { Average standard } \\
\text { error }\end{array}$ & 3.09 & 3.58 \\
\hline
\end{tabular}

Fig.5 Maintenance level boxplots according to the prevalence of black pod

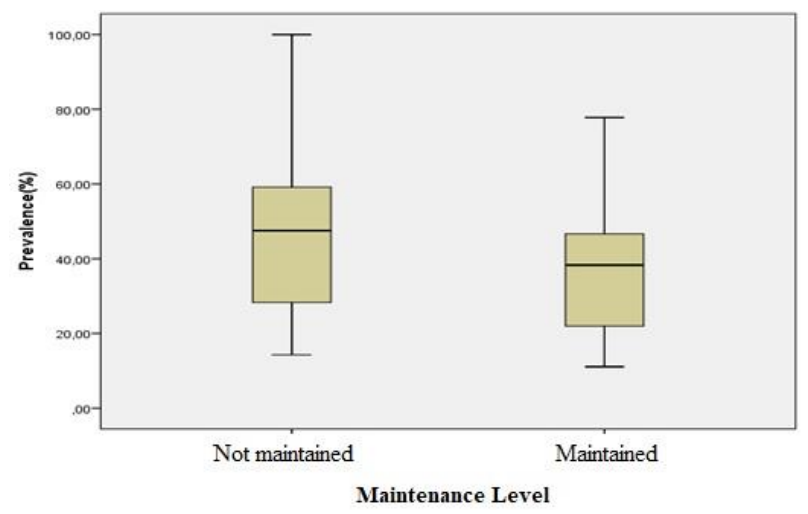

Acknowledgements: Many thanks to the French Agropolis Fondation E-SPACE project which partly funded this work. As well as the agricultural expertise firm Solution Alternative Globale (SAG Sarl) for the implementation of field activities.

\section{References}

1. Akrofi AY (2015) Phytophthora megakarya: Review on its status as a pathogen on cacao in West Africa. African crop science journal,vol.23; No.1, pp.67-87

2. Blaha G (1983) Effet de la lumière sur Phytophthora palmivora et Phytophthora megakarya, agents de la pourriture brune des cabosses du cacaoyer. Etude préliminaire du phénomène de photo-inhibition observe sur Phytophthora megakarya. Café Cacao Thé, 27 (2) : 91-112

3. Cocoa Coffee Council (2015) Manuel technique de cacaoculture durable, à l'attention du technicien. Edition Février 2015, pp 80-83

4. CNRA (2007) Le CNRA en 2007. Édition, maquette, mise en page CNRA, direction des innovations et des systèmes d'information, ISBN 978-2-917074-01-5
5. Coulibaly K, Kébé I B, Koffi N K, Mpika J, Koné D (2013) Caractérisation des isolats de Phytophthora spp du verger cacaoyers de Cote d'Ivoire. Journal of Applied Biosciences 70 :5567- 5579 ISSN 1997-5902

6. Efombagn M I B (1999) La pourriture brune des fruits du cacaoyer (Théobroma cacao L.) due à Phytophthora megakarya : caractérisation du pouvoir pathogène des isolats et de la résistance précoce de familles hybrides. Mémoire de fin d'études, FASA, Université de Dschang. 74 p.

7. Flood J (2006) The threat from global spread of cocoa pests and diseases : hypothetical scenario or clear and present danger. In: proceedings of the 15th International Cocoa Research Conference. 9-10 October 2006. San Jose (Costa Rica), pp.857-872

8. Guyot M (1992) Systématique des angiospermes : référence à la flore du Togo. Edition financée par la Mission Française de Coopération et d'Action Culturelle de Lomé. Diffusion auprès de la bibliothèque de l'Université du Benin, Togo. $217 \mathrm{p}$

9. Kébé I B, (1999) Rapport Annuel d'Activité 1998, Programme Café- Cacao, Cola, CNRA, Côte d'Ivoire

10. Kébé IB, N'goran J A K, Tahi G M, Paulin D, Clément D, Eskes A B (1996) Pathology and breeding for resistance to black pod in Côte d'Ivoire. In: proceedings of the International Workshop on the Contribution of, disease Resistance to cocoa Variety Improvement. 24 th -26 th November, 1996. Salvador, Bahia (Brazil). pp. 135-139

11. Lass T (2004) Balancing cocoa production and consumption. In: Flood J, Murphy R. (eds) Cocoa futures - a source book on some important issues facing the cocoa industry. CABIFEDERACAFE, USDA, Chinchina, Colombia, pp 8-15

12. Matta C (2010) Spontaneous Generation and Disease Causation: Anton de Bary's Experiments with Phytophthora infestans and Late Bright of Potato. Journal of the History of Biology, 43, 459-491

13. Medeiros A G (1976) Sporulation of Phytophthora palmivora (Butl.) Butl. In relation to epidemiology and control of cocoa black pod disease. Ph.D. Thesis, University of California, Riverside, $220 \mathrm{p}$

14. N'go F Z, Azzaoui A O T, Ahami Y, Aboussaleh A L, $\begin{array}{llll}\text { Hamrani A } & \text { (2012) Déterminants }\end{array}$ socioéconomiques environnementaux et nutritionnels de l'échec scolaire : cas des enfants résidant en zone cacaoyère de Soubré (Côte d'Ivoire). Antrop, Vol 28 : pp63-70

15. Pohe J, Koula J, Rabe G R, Dezai L R (2013) Agressivité de la pourriture brune des cabosses de cacaoyer dans le sud-est de la Cote d'Ivoire. Journal of Animal \&Plant Sciences, 2013. Vol.20, Issue 2: 3126-3136 Publication date 31/12/2013, éhttp://www.m.elewa.org/JAPS; ISSN 20717024

16. Pohe J (2012) Phytophthora spp. Agents des maladies de diverses plantes. Rev. Ivoir. Sci. Technol., 19 (2012)

17. pp $72-87$

18. Tarjot M (1971) Nouvelle contribution à l'étude de la pourriture brune des cabosses du cacaoyer due au Phytophthora palmivora (Butl.) Butl. En Côte d'ivoire. Café Cacao Thé, 16(1): $31-48$

19. Yao K T (2009) Hydrodynamisme dans les aquifères de socle cristallin et cristallophyllien du Sud- Ouest de la Côte d'Ivoire : cas du département de Soubré : apports de la télédétection de la géomorphologie et de l'hydrogéochimie, Océan et Atmosphère. Conservation nationale des arts et métiers,

$284 \mathrm{p}$ 